\title{
Silhouette sign revisited
}

\author{
Sharath P Madhyastha 지 , Charan Thej Reddy, Raviraja V Acharya, Shubha Seshadri
}

Internal Medicine, Kasturba Medical College, Manipal Academy of Higher Education, Manipal, Karnataka, India

\section{Correspondence to Dr Sharath P Madhyastha; dr.sharathymc@gmail.com}

Accepted 10 September 2020

\section{DESCRIPTION}

A 30-year-old woman with a 20-year history of bronchial asthma that had been managed with inhaled budesonide and formoterol as needed came with 1-week history of cough, fever and rightsided chest pain. She had normal oxygen saturation while breathing ambient air and was not in respiratory distress. Physical examination was notable for bronchial breath sounds and crackles over right mammary region.

A frontal radiograph of the chest (figure 1) showed airspace opacity in the right lower lung zone. The right heart border is lost and the right dome of diaphragm is well seen, indicating right middle lobe (RML) involvement (silhouette sign). On the other hand, if the right heart border is well seen and the lung opacity obscures the right dome of diaphragm, then the lesion must be in the right lower lobe. The findings were confirmed with CT of chest. (figure 2)

The normal silhouette (outline) of heart and diaphragm can be well seen because of the contrast that exists between the denser cardiac structures (white) and less dense adjacent lung tissue (black). When a part of lung which is adjacent to heart (eg, RML) is consolidated then its density becomes same as that of heart and it cannot be seen separately from the heart. This is called the Silhouette sign. Dr Benjamin Felson coined the term silhouette sign after reasoning that, "An intrathoracic lesion touching a border of the heart, aorta, or diaphragm will obliterate that border. An intrathoracic lesion not anatomically contiguous with a border of one of these structures will not obliterate that border."1-3

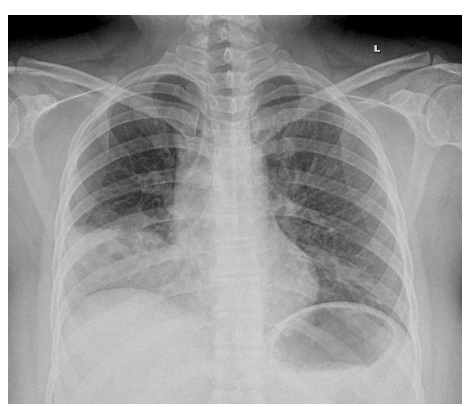

Figure 1 A frontal radiograph of the chest showing airspace opacity in the right lower lung zone. Note that the right heart border is lost and the right dome of diaphragm is well seen.

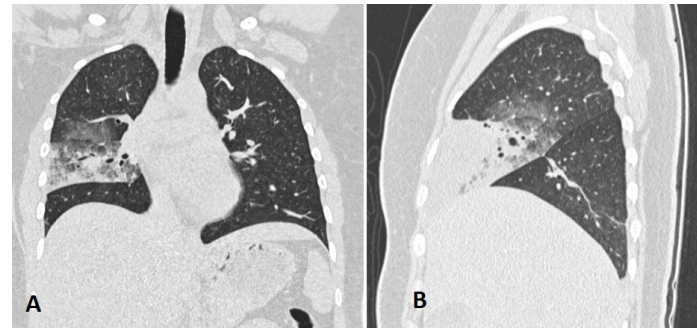

Figure 2 CT of thorax (A: Coronal, B: Sagittal views) showing consolidatory changes with air bronchograms and small cavitation (due to breakdown of consolidation) involving right middle lobe.

\section{Learning points}

- The silhouette sign results from the juxtaposition of structures of similar radiographic density.

- The sign is used not only to identify normal chest structures but also to localise lung diseases.

The patient was discharged after 10 days of antibiotic therapy (moxifloxacin) and was doing well at a follow-up visit 2 weeks after discharge.

Acknowledgements We acknowledge the department of Radiology for providing chest X-ray and CT chest images.

Contributors SPM and CTR wrote the draft of the manuscript. RVA involved in patient management. SS revised the manuscript critically for important intellectual content. All authors contributed to the literature review and approved the final manuscript for submission.

Funding The authors have not declared a specific grant for this research from any funding agency in the public, commercial or not-for-profit sectors.

Competing interests None declared.

Patient consent for publication Obtained.

Provenance and peer review Not commissioned; externally peer reviewed.

ORCID iD

Sharath P Madhyastha http://orcid.org/0000-0003-2821-3473

\section{REFERENCES}

1 Felson B, Felson H. Localization of intrathoracic lesions by means of the postero-anterior roentgenogram; the silhouette sign. Radiology 1950:55:363-74.

2 Murfitt J. The normal chest. In: Sutton D, ed. Textbook of radiology and imaging. Edinburgh: Churchill Livingstone, 1999: 299-353.

3 Algın 0, Gökalp G, Topal U. Signs in chest imaging. Diagn Interv Radiol 2011;17:18-29. 
Copyright 2020 BMJ Publishing Group. All rights reserved. For permission to reuse any of this content visit https://www.bmj.com/company/products-services/rights-and-licensing/permissions/

BMJ Case Report Fellows may re-use this article for personal use and teaching without any further permission.

Become a Fellow of BMJ Case Reports today and you can:

- Submit as many cases as you like

Enjoy fast sympathetic peer review and rapid publication of accepted articles

Access all the published articles

Re-use any of the published material for personal use and teaching without further permission

Customer Service

If you have any further queries about your subscription, please contact our customer services team on +44 (0) 2071111105 or via email at support@bmj.com.

Visit casereports.bmj.com for more articles like this and to become a Fellow 